\title{
THE ORIGIN OF PENITENTS
}

\author{
By Louis Lliboutry
}

(University of Chile)

\begin{abstract}
Penitents are observed on all the snow fields and glaciers of the Santiago Andes between 4000 and $5200 \mathrm{~m}$. They are caused by the prolonged action of the sun in a dry and cold atmosphere. The sublimation of the snow or ice allows the crests to maintain their temperature below $0^{\circ} \mathrm{C}$., while in the spaces or passages between the penitents, where radiation is concentrated and removal of water vapour not so easy, melting takes place. This hypothesis is justified by a brief study of the climate of the high Cordillera of Santiago; this study has been attempted for the first time with the help of meteorological information obtained from La Cumbre $(3837 \mathrm{~m}$.).

The first stage of the penitents is a form of "micropenitent," similar to that observed at the end of the winter below $3500 \mathrm{~m}$. These micropenitents frequently come from crusted snow which has cracked. The compact ice penitents are directly formed from ice, as is proved by the existence of ice micropenitents.
\end{abstract}

Sommaire. Les pénitents s'observent sur tous les champs de neige et glaciers des Andes de Santiago entre 4000 et $5200 \mathrm{~m}$. Ils sont dus à l'action prolongée du soleil dans une atmosphère sèche et froide. La sublimation de la neige ou de la glace permet aux crêtes de se maintenir en dessous de $0^{\circ}$, tandis que dans les couloirs entre pénitents, où les radiations se concentrent et d'où la vapeur s'élimine plus difficilement, la fusion fait son apparition. Cette hypothèse est justifiée par une étude sommaire du climat des Hautes Andes de Santiago, tentée pour la première fois à partir des données météorologiques de La Cumbre $(3837 \mathrm{~m}$.).

Le point de départ des pénitents est constitué par des "micropénitents," analogues à ceux que l'on observe à la fin de l'hiver à moins de $3500 \mathrm{~m}$. Ces derniers se forment souvent à partir d'une neige croûteuse craquelée. Les pénitents de glace compacte se forment directement, comme le prouve l'existence de micropénitents de glace.

\section{I.-INTRODUCtion}

Penitents * are spikes of old compact winter snow or of glacier ice, roughly ranged in an eastwest direction, which in the Andes of Santiago, in summer, cover all the snow fields and glaciers between 4000 and $5200 \mathrm{~m}$. in serried ranks. Lower down they progressively lose their sharp forms as will be described. At higher altitudes the snow remains powdery too long to form penitents.

Since their first observation in 1835 by Charles Darwin at the Paso de los Piuquenes, $\uparrow$ the most fanciful theories on their origin have been proposed. Darwin attributed them to the wind, Brackebusch in $\mathrm{r} 893$ to the cracks created by the descent of the snow on landslides, Conway in I 902 to the action of the sun on the snow from avalanches, Meyer in 1908 to melting by a warm west wind, Catalano in 1926 to the electromagnetic orientation of snow crystals, and Hess in I 933 to thermal eddies of the air and to the rain.

These theories ignored the fact that the penitents are found over all the snow fields of a climatic region and that they all lie in an east-west direction. The disturbances from this direction can be explained by non-symmetric insolation, due to cloudy evenings (Klute in 1914), or merely to the orientation. For instance in a steep couloir facing south-west, at $4550 \mathrm{~m}$., there were at the end of January I 953 penitents $80 \mathrm{~cm}$. high, whose direction was $75^{\circ}, 255^{\circ}$ instead of $90^{\circ}, 270^{\circ}$.

In 1942 Troll published a fundamental book Büsserschnee, ${ }^{1}$ collecting no less than 127 references. Many of the names referred to here will be found among those references if not listed among those of the present article. Troll clearly distinguished penitents from other features of snow fields due to transport or erosion by the wind or by melt water, or to differential ablation (glacier tables, dirt cones, cryoconite holes, ice pyramids and the like). He fully understood that penitents were simply due to the sun's rays striking a uniform surface, and that no previous structure of the snow plays any part. As Kaufmann has already noted, when equilibrium cannot be established a

* We venture to translate the words used by Chileans and Argentinians into English: penitentes (noun), campo de penitentes (field of penitents). Niere penitente is not used, and niere de los penitentes means "snow from the penitents." Both expressions have been introduced into international literature by foreign glaciologists who did not know Spanish very thoroughly. In German the two different words Büsserschnee and Zackeneis are used to designate the same single phenomenon.

[In point of fact Professor C. Troll (Ref. I, p. 338) uses the word Büsserschnee as the translation of nieve de los penitentes, but Professor Lliboutry's use of the English word "penitents" seems more satisfactory than the expression mieze penitente hitherto used by writers in English. $-E d$.]

$\uparrow$ Paso: a pass with a mule track between Argentina and Chile. The Paso de los Piuquenes is the nearest to Santiago, at the bottom of Río Yeso valley. 
continuous cause can produce periodically recurring effects, such as the grinding of chalk on a blackboard (relaxation oscillations), the thermal eddies on hot, flat land, the meanders of a river or the corrugation on earth roads. Troll was able to reproduce penitents in Germany by shining an electric bulb on fresh snow during a cold, dry night.

Troll thinks that direct sublimation or rapid evaporation of melted water, as well as night frost, are indispensable (Rossmann in 1930 noted the importance of nocturnal outgoing radiation). But the mechanism itself of the formation of penitents has not yet been explained. It is a physicist's problem, and Troll could only gather information from "andinists" and geologists.

\section{II.-The Mechanism of Formation of Penitents}

A striking feature of the fields of penitents that nobody has yet pointed out must first be emphasized, namely the difference of temperature which appears during a sunny day between the penitents and the intermediate spaces between them. When the spikes or blades remain hard and dry, the snow between them becomes soft and set, and even rotten, soaked with melt water. In the case of ice penitents there is often liquid water, streamlets and puddles between them, which, when flowing off from a field of penitents above a cliff, form frost cascades of ice. This is proof that the temperature in the passages between penitents is higher than in the surrounding air.

We shall first refer to snow penitents. They are composed of snow from the previous winter, which is of about the same density $(0.5$ to 0.7$)$ and grain size as three-year-old alpine snow.*

Let us suppose first that the whole surface of a snow field is at $0^{\circ} \mathrm{C}$., as happens in the Alps during a sunny spring day. The least depression tends to grow deeper, as the sun's rays have more chance to be reflected several times, so that radiant heat is better absorbed. But, as the melt water experiences more difficulty in leaving a hole (either by capillarity or by evaporation), the increase in depth cannot go too far. The final aspect is the well-known "honeycombed snow." The author has observed this several times in the French Alps, when a sunny and hot period has followed abundant snowfalls in April or May, for instance on I June 1947 , at about $2300 \mathrm{~m}$., over the Jean Collet hut (Chaine de Belledonne), and particularly on 28 June $195^{\circ}$, at the same altitude, on the Glacier du Chardon (Oisans).

During a sunny day at the end of winter or in spring the surface of the snow in central Chile generally does not melt as it does in the Alps; it sublimes instead. The dew point must be below $0^{\circ} \mathrm{C}$. The surface temperature of the snow rises more or less above the dew point, so that the loss of heat by sublimation and outgoing radiation and its gain by solar radiation and air conduction may balance. Let us suppose that the air temperature is so low as to make air conduction negligible. Then, if one-tenth of the solar radiation is absorbed, the sublimation will be of about $0.1 \mathrm{gm} . / \mathrm{cm} .^{2}$ of ice an hour. So low a rate implies that the superficial temperature is not very much above the dew point. Paradoxically, the drier the air the lower the dew point and the lower the ablation. We find here the factor of instability which Kaufmann assumed.

Then as a small depression deepens the increase in depth brings in a new factor. Not only is the heat absorbed greater, but the dew point is also higher. So the superficial temperature rises in the hollow and the ablation in it becomes faster and faster. The crests take the form of east-west blades, bending to the sun (that is to the north) - the form which allows the most outgoing radiation and sublimation, and the least insolation, for a given cross-section. The intermediate spaces deepen. They become almost a black body for solar radiation, while the humidity of the air increases in them. Finally the superficial temperature in the spaces reaches $0^{\circ} \mathrm{C}$. and melting starts.

From this moment we have alternately troughs where the snow melts and penitents where it sublimes. In both cases the speed of the process depends on the thermal balance, so that melting goes further than sublimation. While the superficial temperature is always $0^{\circ} \mathrm{C}$. in the spaces, on the penitents it is negative and dependent on the speed of sublimation.

\footnotetext{
* We propose to call this firn snow or firn, establishing between firn and névé the difference suggested by Seligman. The study of the snow-ice transformation, in connexion with penitents, will be dealt with in another article.
} 
There have been many discussions as to whether sublimation or melting preponderate at high altitudes. ${ }^{2}$ As will be seen, it depends on whether the surface is flat or carved into penitents. Although sublimation is indispensable for penitent formation, in a field of penitents most of the ablation proceeds from melting.

In the deep layers, which remain below $0^{\circ} \mathrm{C}$., or at the bottom of the penitents, melt water freezes again. When coming off from the field of penitents melt water also freezes, or evaporates. Before the formation of penitents the ice so formed sublimes. Thus, finally, a great part of the water stored in the Cordillera during winter disappears as vapour instead of swelling the rivers. This is an important factor in the irrigation problem in Chile and Argentina.

\section{III.-Climatic Conditions of Formation}

The conditions which give rise to penitents are then:

(I) The dew point definitely below $0^{\circ} \mathrm{C}$., that is to say a very small amount of water vapour in the air.

(2) Strong insolation.

(3) Air temperature never strongly positive, so that the heat brought by the air cannot interrupt the process. It must not be too low, however, as penitents cannot form in powder snow.

(4) In addition, if the air is rarified owing to the altitude, this increases the speed of sublimation and hastens the formation of penitents. When penitents have been observed in very high mountains it is only because in the dry sub-tropical regions there is snow only at high altitudes; but this condition is not essential and, in fact, penitents have been observed at very low altitudes, for example on the north-east coast of Greenland ${ }^{3}$ and in the Antarctic. ${ }^{4 a,}, b$

The wind certainly increases the speed of evaporation, but, owing to its tendency to make both humidity and temperature uniform over the whole field of penitents, it is a disturbing factor. In fact penitents are specially developed on leeward slopes. For instance at the Paso de los Piuquenes $(4030 \mathrm{~m}$.) in January 1953 there were fields of penitents $1 \mathrm{~m}$. high on the Argentine side ; two superficial snowslides having locally destroyed them, new penitents, $30 \mathrm{~cm}$. high, were carved out in a week. But on the windy Chilean side there existed only a few intermediate forms.

It will be seen, however, that wind can be useful in the early stages of formation.

It is evident that the four conditions mentioned above prevail in the high Cordillera between Santiago and Mendoza, but meteorological data are wanting. The only published data are those of El Teniente (23I4 m.), on the Chilean side, and of Puente del Inca (2700 m.) in a deep valley on the Argentine side. These places are too low; the monthly averages published by Troll are also of little assistance. Fortunately for ten years there has been a meteorological station of the Pan American Grace Airways Co. at the Paso de La Cumbre $(3837 \mathrm{~m}$.) which gives out hourly bulletins between 04.00 and $19.00 \mathrm{hr}$. Nevertheless, on days of bad weather temperature values are not very reliable. Besides, the amount of precipitation is not measured, but, for the study of the ablation, this is of secondary importance.

The Paso de La Cumbre, between Aconcagua (6956 m.) and the Nevado Juncal (6r ro m.) groups, is at the end of a transverse valley. Abnormally strong west winds prevail here and can bring humidity from the Pacific Ocean; the humidity figures will be maximum ones for the high Cordillera. The Cerro Tolosa to the north-east, $24^{\circ}$ above the horizon, hides the sun during the first two hours of the day, so that the rising of temperature in the morning is abnormally fast for a point on a ridge such as this.

The following climatic data are pertinent.

The mean temperature at La Cumbre is $-1 \cdot 0^{\circ} \mathrm{C}$., that is $14.9^{\circ}$ less than in Santiago $(520 \mathrm{~m}$.). This somewhat small difference is due to an inversion of temperature which prevails at $1500 \mathrm{~m}$. In fact Santiago, built at the end of the central Chilean valley, between the Cordillera de la Costa 
(Coast Range) and the Cordillera de los Andes, is generally covered by a stagnant mass of polar air and has a different climate to the coast or the Andes.

In Fig. I (p. 335) the number of days in a month with a snowfall is quoted for La Cumbre (in black). It rains once a year here. In white are figured the days without any cloud except at most during two or three hours at sunrise or at sunset (but not at both). The number of days with wind reaching 40 knots or more during the day (gusts excluded) is quoted on the same Figure.

We can see that the bad weather appears abruptly in May. But although it gets better progressively in Santiago from June to January, in the Cordillera it remains bad until November. Even in many years August is better than September. As in the Alps, the climate has a tendency increasingly to assume continental features with altitude. The snowfalls of October and November are of wet heavy snow, not blown off by the westerly winds on lee slopes.

In December and January cumulus appears most evenings. The secondary maximum of snowfalls in February proceeds from local storms. The finest weather occurs in March, with whole weeks without a cloud. In consequence, the mean temperature is abnormally low in September, October, November, and high in April (Fig. 2, p. 335).

For the study of ablation we must know the air temperature and the dew point at each hour of the day, $(a)$ during sunny days, in order to know whether penitents can be formed; $(b)$ during overcast days, in order to know whether any penitents which have been formed will be destroyed. The calculation of mean values has been made for the spring and summer days of $195^{2}$ (which was a very normal year), and the results are quite different (Fig. 3, p. 335). As the sunny days of spring were too scarce the average value including $195^{\mathrm{I}}$ was taken after a uniform correction, in order that the general mean temperature should not be disturbed.

In spring the region is covered with snow, so that the air becomes cold on overcast days. The dew point increases during the day, owing to evaporation of the snow fields. In summer the region is almost completely bare of snow, so that the air can be warmed by the bare earth during overcast days. The humidity comes from the ocean, and is thus quite different on sunny days (southerly wind) and overcast days (north-easterly wind). But the dew point at La Cumbre, in spite of its open position, always remains very low.

In spring, on sunny days, the humidity is about 30 per cent and the temperature is about $\circ^{\circ} \mathrm{C}$. and penitents can appear. On overcast days the temperature is well below zero, so that the penitents cannot melt. In fact we observe small penitents (micropenitents).

In summer, on sunny days, the humidity is about 25 per cent, and although the air temperature is about $8^{\circ} \mathrm{C}$. the dew point is well below $0^{\circ} \mathrm{C}$. The action of solar ablation is faster than that of air conduction and penitents can appear (on patches of snow facing south). But on nights and on overcast days the temperature is also positive, so that general melting goes on and tends to obliterate the penitents. In fact we observe intermediate forms between penitents and "honeycombed snow," and we must reach $4500 \mathrm{~m}$., where the temperature is $4^{\circ}$ lower and it freezes during the night, to find true penitents.

We observed that, between August and February, the lower limit of true, typical penitents rises from $2700 \mathrm{~m}$. to $4500 \mathrm{~m}$. Air temperature is the governing factor, as the dryness condition is always fulfilled. Penitents formed in spring, at too low an altitude, melt in summer, passing through an intermediate form of "sun spikes," which seem to be similar to those observed by Workman in the Karakoram. ${ }^{5}$ In the Andes of Santiago the author observed several times in January, when climbing from 3500 or $3800 \mathrm{~m}$. to $4500 \mathrm{~m}$., the gradual passage from "honeycombed snow" to "sun spikes" with their tops rounded, and from "sun spikes" to penitents. A similar observation was made by Matthes on Mount Rainier. ${ }^{6}$ According to photographs of Ostrowski (Fig. 4, p. 337), both types seem to coexist at the top of the Kilimanjaro.

As we go north, snowfalls become rarer and more irregular and the sunny periods between them increase. Penitents, which are in general $\mathrm{I}$ to $2 \mathrm{~m}$. high at the latitude of Santiago (lat. $33^{\circ} \mathrm{S}$.), can reach unusual heights. The Chilean expedition of November 1949 to Nevado Ojos del Salado ( $686_{3} \mathrm{~m}$., lat. $27^{\circ} \circ 6^{\prime}$ S.) found penitents 5 to $8 \mathrm{~m}$. high, at $6000 \mathrm{~m}$. (Fig. 5, p. 337). 
The first climbers of Volcan Llullaillaco $\left(6723\right.$ m., lat. $24^{\circ} 43^{\prime}$ S.) on I December $195^{2}$ found a field of snow penitents $\mathrm{I} \mathrm{m}$. high at $4800 \mathrm{~m}$. That year was exceptionally wet for the northern Chilean desert. But on the west slope, between 5600 and $6500 \mathrm{~m}$., there was a field of compact ice without penitents. This place is the southern limit of the "Bolivian winter" in Chile (i.e. some snowfalls from December to March due to the Atlantic influence).
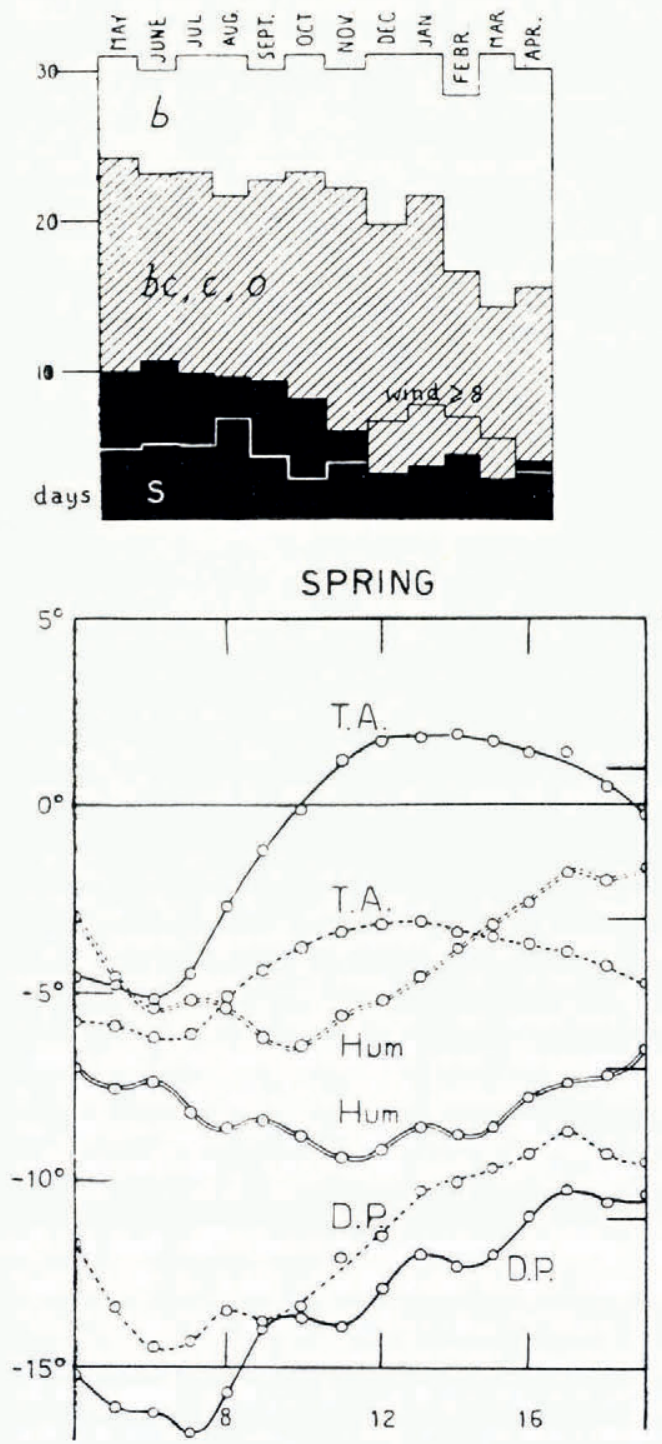
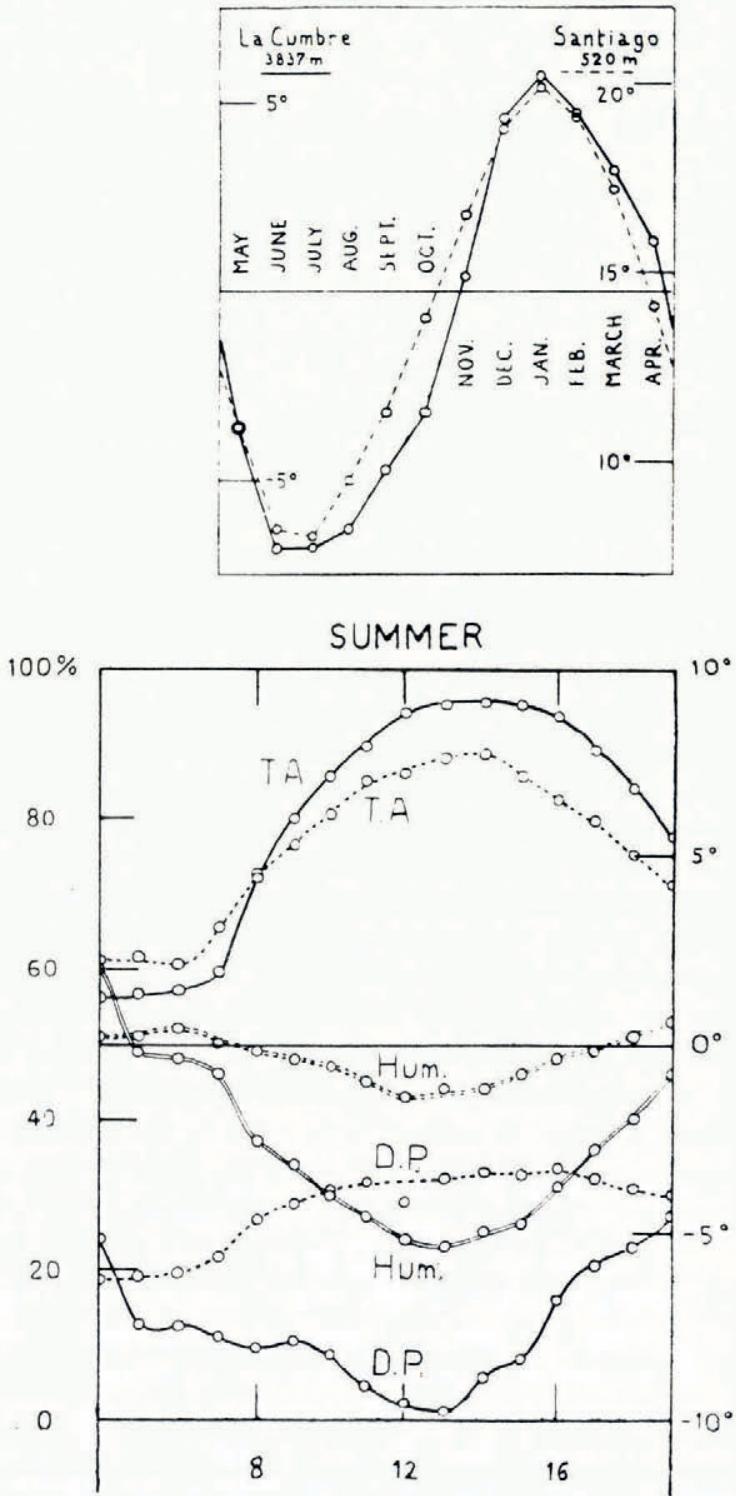

Fig. I (above left). Mean number of day's at La Cumbre with clear sky (b), cloudy or overcast (bc, c, o), with snowfall (black) and with winds greater than force 8

Fig. 2 (above right). Mean temperatures at La Cumbre (continuous line and scale at left margin) and at Santiago (broken line and scale at right margin)

Fig. 3 (below). Air temperatures (T.A.), dew point (D.P.) and relative humidity (Hum.) during sunny days (continuous lines) and overcast days (dotted lines) at La Cumbre 


\section{IV.-The Initial Phase-Micropenitents}

For convenience, we propose to call micropenitents the penitents of only a few centimetres, at most $\mathrm{I}_{5} \mathrm{~cm}$. high, which do not impede walking or even ski-ing. They have rarely been mentioned-by Keidel in Argentina, by Barrera in Chile, ${ }^{7}$ and, casually, by Rossmann in the Schwarzwald and by Jaeger in the Bernese Oberland. In the Andes of Santiago they appear frequently at the end of the winter, before the last snowfalls of October-November, at heights less than $3500 \mathrm{~m}$. In this case they do not cover the whole of a region and so seem to depend more on local factors. Also they appear higher and over greater areas in October-November. We observed them specially in the following circumstances:

\begin{tabular}{|c|c|c|c|}
\hline Date & Place & Altitude & Mean height \\
\hline $\begin{array}{l}7 \text { June 1953 } \\
\text { 10 August } 1952 \\
2 \text { September } 1951 \\
\text { 12 October } 195^{1} \\
26 \text { October } 195^{2} \\
9 \text { November } 1953\end{array}$ & $\begin{array}{l}\text { Farellones (ski-ing resort) } \\
\text { South-west of La Parva de Farellones } \\
\text { Western slope of Cerro Colorado (Farellones) } \\
\text { Quebrada Valdés (near Volcan San José) on an } \\
\text { avalanche cone } \\
\text { Southern slope of La Copa pass (near La Disputada } \\
\text { copper mine) } \\
\text { Everywhere above La Disputada }\end{array}$ & $\begin{array}{l}2650 \mathrm{~m} \\
2900 \mathrm{~m} \text {. } \\
2900 \mathrm{~m} \\
2700 \mathrm{~m} \text {. } \\
3700 \mathrm{~m} \text {. } \\
3400 \text { to } 4000 \mathrm{~m} \text {. }\end{array}$ & $\begin{array}{l}2 \mathrm{~cm} \\
5 \mathrm{~cm} \\
8 \mathrm{~cm} \\
12 \mathrm{~cm} \\
15 \mathrm{~cm} \\
3 \text { to } 15 \mathrm{~cm} \text {. }\end{array}$ \\
\hline
\end{tabular}

They were all composed of very much altered snow (spherical crystals cemented together). Except for their small size and their greater inclination due to the still low meridian height of the sun, nothing distinguished them from normal penitents, several metres high. Nevertheless, in winter the spaces between micropenitents often remain dry at the end of a sunny day. In spring, on the contrary, the micropenitents themselves often begin to melt at the end of a sunny day.

Micropenitents are the initial phase of the fields of penitents, and the author will continue to study them. On two occasions micropenitents which had not yet reached their normal form were observed close to normal micropenitents, and it reveals a possible first phase in their development. It cannot be asserted, however, that this is always the case; ripples made by the wind or holes due to insolated pebbles may be another starting-point.

These two occasions occurred in crusted snows, which are very common at low altitudes after several hot days. The speed of their transformation allows them to remain dry and almost powdery under the crust. When cracks are formed in this crust the wind blows off the powder snow below, carving out a net of little furrows, which the sun transforms in the course of time into micropenitents. On ro August $195^{2}$, at about $2700 \mathrm{~m}$. at Farellones, the initial cracks were due to the sinking of the snow on a horizontal surface. The broken crust turned over and formed the upper south face of micropenitents $10 \mathrm{~cm}$. high, progressively extending from old ski tracks (Fig. 6, p. 337). On 26 October $195^{2}$, at La Copa pass (3780 m.), it was the sliding of the snow down the slope which had broken the crust into east-west cracks, which had then been excavated by the wind into narrow channels $30 \mathrm{~cm}$. deep.

Theoretically a single furrow can cause a whole field of penitents to form. The wall of the depression, in which sublimation and radiation can take place more easily, must be at a lower temperature than the surrounding snow surface; it therefore soon appears in accentuated relief. Two parallel furrows will form on each side of the initial one. At this stage a footprint will appear much enlarged, and this may perhaps help to explain the extraordinary footprints observed by Eric Shipton on his way to Mt. Everest. By degrees successive furrows will appear, and from a few hollows a whole field of penitents will be formed.

\section{V.-Micropenitents and Penitents of Ice}

When the snow field lies directly upon the ground, the channels between the penitents often succeed in reaching the ground, and the penitents, detaching themselves from one another, assume 

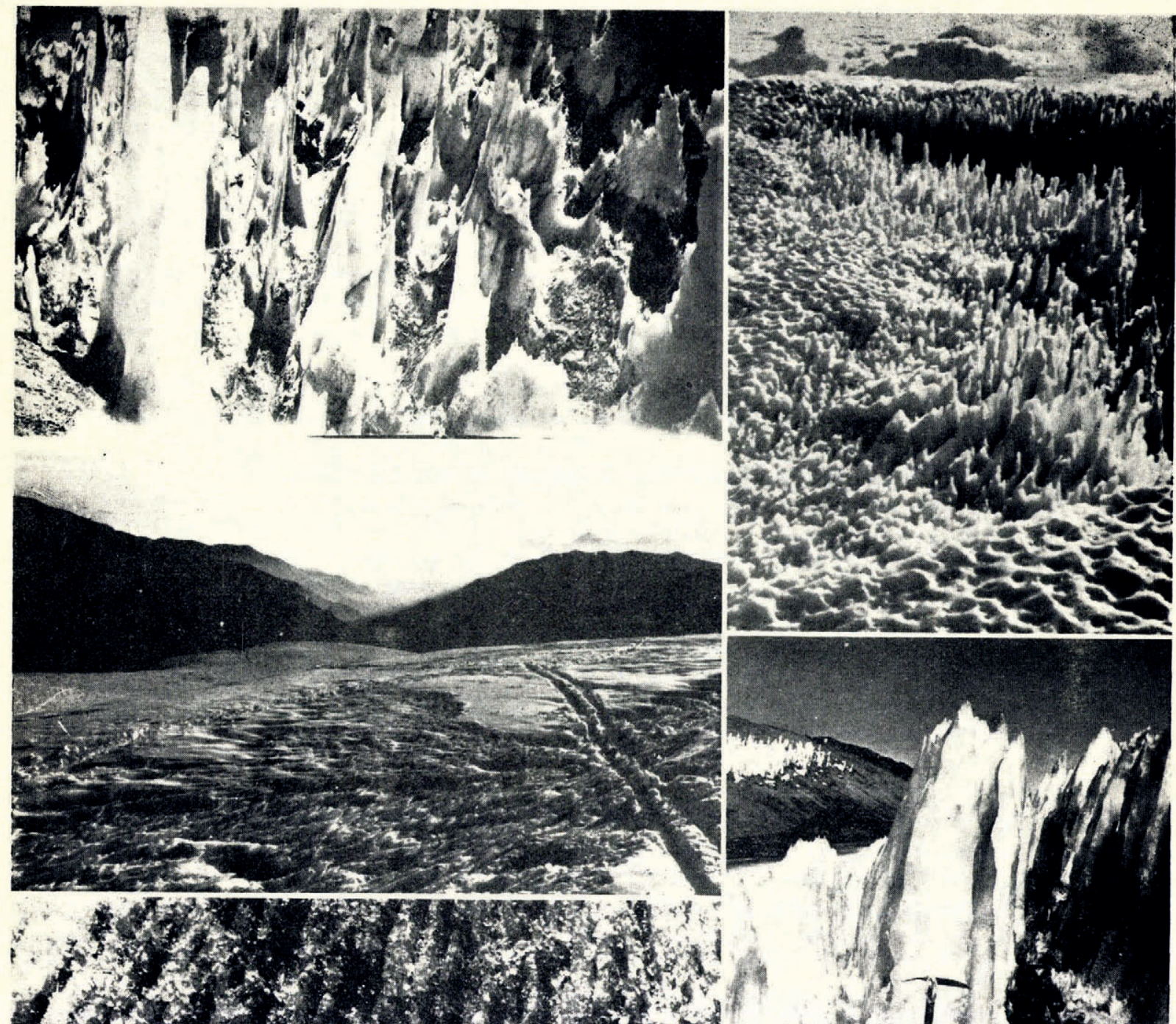

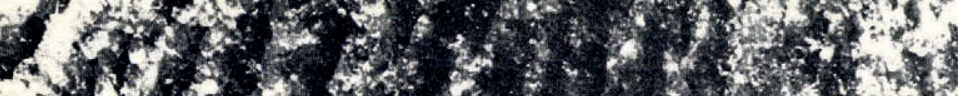

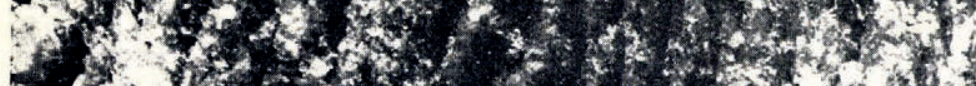

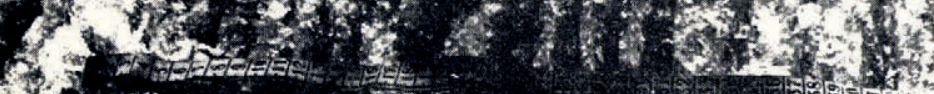

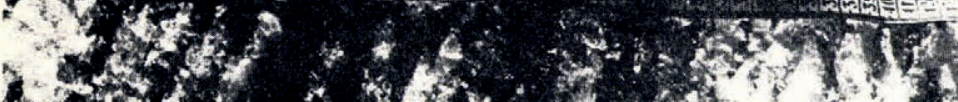
15. Fig. 4 (top left). Penitents on the summit of Kilimanjaro

Fig. 5 (top right). Penitents at Nevado Ojos del Salado at about $6000 \mathrm{~m}$. in November 1949

Fig. 6 (centre). Micropenitents formed from a sunk snow crust near old ski tracks at Farellones (27oo m.) in August

Fig. 7 (bottom right). Ice penitents at the top of the Olivares Beta Glacier (at the foot of Cerro Negro) at
distance (towards the east) snow penitents Fig. 8 (bottom left). Micropenitents of ice on a frozen pool at about $4600 \mathrm{~m}$. in Fanuary

Photograph by L. Lliboutry about $4600 \mathrm{~m}$. In the Photograph by L. Lliboutry 22

Photograph by L. Lliboutry 
the vague appearance of an Easter procession of white-cowled Spanish penitents. Generally they fall to the north and disappear before May.

When the penitents of snow lie on a glacier, it may happen that the channels reach the ice and continue down into it. So on the glaciers, at about $4600 \mathrm{~m}$., penitents of pure compact ice, almost without air bubbles, are the general rule (Fig. 7, p. 337). On the average their horizontal length is greater than that of the comparatively short snow penitents.

From a distance it is very difficult to distinguish them from penitents of old snow, the more so as those of snow generally have glazed frost on the south side (probably because this side is slightly in the shade, as the height of the sun decreases during the summer). There are few observations of penitents of ice. Reichert gave them the name of "Zackeneis," as he thought they were created by parallel cracks in the glacier. He probably confused them with the narrow ridges of the cracked Patagonian glaciers in their lower reaches, as many others have done.

A. Maas (as reported by Troll) supposed that the penitents of ice were penitents of snow transformed without losing their form. Although the author is convinced of the transformation of the snow into ice at the surface, without the interference of pressure, the uniform structure of ice penitents and the lack of observed intermediate stages are contrary to Maas's theory.

Glacier ice can be moulded into penitents by the same mechanism as firn snow. On two occasions well-marked micropenitents of ice were observed on frozen pools at about $4600 \mathrm{~m}$., at points where exceptionally heavy thawing had taken place. The intermediate spaces lay east-west and were about $3 \mathrm{~cm}$. apart, $5 \mathrm{~cm}$. deep and several decimetres long (Fig. 8, p. 337). Ripples of the water had perhaps been the starting-point.

At a lower altitude, for instance on the Ventisquero Juncal Sur, at about $3800 \mathrm{~m}$., or on the Ventisquero Colgante (N-E) del Juncal, at about $4000 \mathrm{~m}$., fluted seracs are to be seen, like those observed by Workman in the Karakoram. It is uncertain whether they correspond to "honeycombed snow" or are due to erosion by melted water.

\section{ACKNOWLEDGEMENTS}

To the University of Chile (Facultad de Filosofía y Educación), which supported several expeditions, and to the Panagra Airways Co., which allowed the author to examine the meteorological bulletins of La Cumbre.

\section{MS. received 8 fune 1953}

\section{R E F E R E N C E S}

1. Troll, Carl. Büsserschnee in den Hochgebirgen der Erde. Petermanns Geographische Mitteilungen, Ergänzungsheft, Nr. 240. Gotha: Justus Perthes, 1942.

2. Church, J. E. Further on the evaporation and melting of snow at high altitudes. fournal of Glaciology, Vol. 2, No. 13, 1953 , p. $233-35$.

3. Odell, N. E. Ablation at high altitude and under high solar incidence. American fournal of Science, Vol. 239, 1941,

4. (a) Wright, C. S., and Priestley, R. E. British (Terra Nora) Antarctic Expedition 1910-1913, Glaciology. London: Harrison and Sons, 1922 .

(b) Personal communication from Prof. Humberto Barrera

5. Workman, William H. Nieve penitente and allied formations in Himalaya or surface-forms of névé and ice created or modelled by melting. Zeitschrift für Gletscherkunde, Bd. 8, 1914, p. 289-330.

6. Matthes, F. E. Ablation of snow at high altitudes by radiant solar heat. Transactions American Geophysical Union, 15th Annual Meeting, April 26-28, 1934, p. 380-85.

7. Barrera, Humberto. A study of the "Nieve penitente" of the Chilean Andes. Union Internationale de Géodésie et de Géophysique, Association Internationale d'Hydrologie Scientifique. Assemblée Générale à Edimbourg, 14-26 Septembre 1936. (Riga, 1938.) Bulletin No. 23, Deuxième partie, p. $5^{8} 7-622$. 